\title{
Erratum: Analysis of the new homotopy perturbation method for linear and nonlinear problems
}

Ali Demir ${ }^{1 *}$, Sertaç Erman ${ }^{1}$, Berrak Özgür ${ }^{1}$ and Esra Korkmaz²

\section{"Correspondence:} ademir@kocaeli.edu.tr

'Department of Mathematics, Kocaeli University Umuttepe, Izmit, Kocaeli 41380, Turkey

Full list of author information is

available at the end of the article
The name of the author Berrak Özgür was incorrectly spelled in [1] as Berrak Özgü. The correct spelling is Berrak Özgür. The publisher apologises to the author for this error.

\section{Author details}

'Department of Mathematics, Kocaeli University Umuttepe, Izmit, Kocaeli 41380, Turkey. ${ }^{2}$ Ardahan University, Merkez, Ardahan, 75000, Turkey.

Received: 1 April 2015 Accepted: 2 April 2015 Published online: 29 April 2015

Reference

1. Demir, A, Erman, S, Özgür, B, Korkmaz, E: Analysis of the new homotopy perturbation method for linear and nonlinear problems. Bound. Value Probl. 2013, 61 (2013)
C 2015 Demir et al.; licensee Springer. This is an Open Access article distributed under the terms of the Creative Commons Attribution License (http://creativecommons.org/licenses/by/4.0), which permits unrestricted use, distribution, and reproduction in any medium, provided the original work is properly credited.
Submit your manuscript to a SpringerOpen ${ }^{\circ}$ journal and benefit from:

- Convenient online submission

- Rigorous peer review

- Immediate publication on acceptance

- Open access: articles freely available online

- High visibility within the field

- Retaining the copyright to your article

Submit your next manuscript at $\boldsymbol{s p r i n g e r o p e n . c o m ~}$ 